УДК 111:27

DOI 10.18413/2712-746X-2020-45-4-604-613

\title{
Мистика мастеров и мистика женщин: к вопросу о соотношении теоретической и опытной мистики
}

\author{
Реутин М.Ю. \\ Российская академия народного хозяйства и государственной службы \\ при Президенте Российской Федерации, \\ Россия, 119571, Москва, проспект Вернадского, 82 \\ E-mail: mreutin@mail.ru
}

\begin{abstract}
Аннотация. Соотношение опытной и теоретической мистики автор демонстрирует на материале письменности немецких доминиканок первой половины XIV века и трудов И. Экхарта, Г. Сузо и И. Таулера. В статье показано, как тот или иной феномен, относящийся к области опыта, получает описание и толкование в понятиях средневековой философии (внутренняя атрибутивная аналогия, субсистенция и пр.) так, что философские построения становятся последовательной транскрипцией феноменов опыта.
\end{abstract}

Ключевые слова: мистицизм, схоластика, транскрипция опыта, внутренняя атрибутивная аналогия, жизнеобеспечение, мистическое единство с Богом.

Для цитирования: Реутин М.Ю. 2020. Мистика мастеров и мистика женщин: к вопросу о соотношении теоретической и опытной мистики. NOMOTHETIKA: Философия. Социология. Право. 45 (4): 604-613. DOI 10.18413/2712-746X-2020-45-4-604-613

\section{The Mysticism of the Masters and the Mysticism of the Women: on the Question about the Relation between the Theoretical and the Experiential Mysticism}

\author{
Mikhail Ju. Reutin \\ The Russian Presidential Academy of National Economy and Public Administration \\ 82 Vernadsky Avenue, Moscow, 119571, Russia \\ E-mail: mreutin@mail.ru
}

\begin{abstract}
This article is devoted to the relation between the experiential and the theoretical mysticism and demonstrates this relation on the material of the writings, belonging to German women-Dominicans from the XIV century and the writings of J. Eckhart, H. Suso and J. Tauler. The research is aimed to demonstrate, how one or the other experiential phenomenon receives a description and an explanation in concepts of the medieval philosophy (intrinsic attributive analogy, subsistence, etc.), so that philosophical structures become a methodical description of the phenomena of the everyday experience.
\end{abstract}

Keywords: mysticism, scholasticism, transcription of the experience, intrinsic attributive analogy, subsistence, mystical unity with God.

For citation: Reutin M.Ju. 2020. The Mysticism of the Masters and the Mysticism of the Women: on the Question about the Relation between the Theoretical and the Experiential Mysticism. NOMOTHETIKA: Philosophy. Sociology. Law series. 45 (4): 604-613 (in Russian). DOI 10.18413/2712-746X-2020-45-4604-613 


\section{І. Вводные замечания}

\section{1. Два уровня мистической традищии}

Немецкая мистика 1-й половины XIV в. представляет собой чрезвычайно удобное поле для постановки и, по крайней мере, пробного, предварительного решения этой сложной проблемы - проблемы соотношения вполне себе абстрактных, отвлеченных философских построений и повседневного опыта и поведения тех или иных групп населения. В самом деле, немецкая мистика позднего Средневековья вызывает в памяти имена как известных ее теоретиков - Мастера (Иоанна) Экхарта фон Хоххайм (ок. 1260-1328), Генриха Сузо (1295/1297-1366), Иоанна Таулера (1300-1361), так и ее практиков, главным образом женщин, из окормляемых ими бегинажей и доминиканских монастырей, в том числе обителей Унтерлинден (Кольмар), Адельхаузен (Фрайбург в Брайсгау), Кирхберг (Зюльц), Готтесцелль (Ульм), Отенбах (Цюрих), Тёсс (Винтертур), Катариненталь (Диссенхофен), Вайлер (Штуттгарт) и Энгельталь (Нюрнберг). Эти женские монастыри выделяются из общего ряда тем, что в них была создана богатая письменность - сестринские книги, откровения и благодатные жития, - являющаяся в известной степени транскрипцией культивируемого в них опыт ${ }^{1}$.

Итак, перед нами вырисовывается в целом 2-уровневая конфигурация немецкой мистической традиции XIV в. Справедливости ради нужно заметить, что традиция эта была несколько более сложной и дробной (что, однако, не противоречит ее 2-уровневому строению). Обратим внимание на разрабатываемые в ее пределах жанры. Известный медиевист и историк мистики П. Динцельбахер разделяет относящиеся к этим жанрам произведения на «мистософские», «мистагогические» и собственно «мистические» [Dinzelbacher, 2012, 10-11]. В мистософских сочинениях рационально доказывается возможность опыта unio mystica и выстраивается образ мира, в котором этот опыт становится не маргинальным, но значимым и даже центральным («Трехчастный труд» И. Экхарта, «Книжица Истины» Г. Сузо). Мистософские произведения близки к собственно научным богословским трактатам, но предполагают некоторую переверстку имеющегося в таких трактатах знания и расстановку новых акцентов, в чем угадываются интересы и нужды аскетического и экстатического опыта. Мистагогические сочинения, являются своего рода руководством для харизматиков, исходя из уже доказанной возможности мистического опыта, и сосредотачиваются на его насущных вопросах. В них предлагаются мотивы и ряды образов, в которых организуется (а не только записывается) экстатический опыт. Ортодоксальный опыт противопоставляется опыту еретиков-пантеистов; обговариваются закономерности и условия и его протекания (толкование на Песнь Песней Бернарда Клервоского и Уильяма Сен-Тьерри, гл. 46-53 автобиографии «Vita» Г. Сузо) ${ }^{2}$. Наконец, в мистических сочинениях изображается сам так или иначе воспитанный опыт («Откровения» Элсбет фон Ойе, М. Эбнер, монахинь Хельфты). Таким образом, предполагая несколько уровней

${ }^{1}$ Сохранились имена авторов (вернее, редакторов) некоторых из этих книг: Катарина фон Геберсвайлер (Унтерлинден), Анна фон Мюнцинген (Адельхаузен), Элизабет Кирхбергская (Кирхберг), Элизабет Штагель (Тёсс) и Кристина Эбнер (Энгельталь). К приведенному списку должен быть отнесен цистерцианский (но курировавшийся доминиканцами) монастырь Хельфта (Саксония), где в последней четверти XIII в. проживали визионерки Мехтхильда Магдебургская, Гертруда Великая и Мехтхильда Хакеборнская, а также доминиканский монастырь Мединген в г. Диллинген (на Дунае), в котором подвизалась автор «Откровений» Маргарет Эбнер (сер. XIV в.).

${ }^{2}$ К мистагогическим сочинениям, несомненно, должны быть отнесены проповеди и краткие изречения («шпрухи») так называемых «малых мастеров»: Иоанна фон Штернгассен, Гартманна фон Кроненберг, Генриха из Эгвинта, Арнольда дер Роте, Генриха из Лёвена, Брата Франке из Кёльна, Иоанна Франко, Брата Экхарта Младшего, Флорентия Утрехтского, Кармелита Хане, Альбрехта из Треффурта, Экхарта Рубе, Хельвика Гермарского, Гизелхера фон Слатхайм, Крафта фон Бойберг и Брата Тюринга. 
абстрагирования, теоретическая мистика где-то подходит и даже смыкается с мистикой практической, что делает общую картину более достоверной и в то же время не отменяет 2-частного строения мистической традиции в целом.

\section{2. Две логики и два описания}

Какое же место в подобной конфигурации отведено профессиональному богословию? Ответим на этот вопрос словами классика немецкой германистики и медиевистики Г. Грундманна: «Теологическая система и спекулятивные учения германских мистиков являются как раз не основой, исходным пунктом и источниковой базой, но рациональным осмыслением, попыткой теоретического упорядочения и богословского освоения тех религиозных практик, которые сначала произросли в опытной мистике религиозного движения женщин» [Grundmann, 1935, 430-431].

Как видим, поведенческие и психологические феномены из повседневного быта бегинок и доминиканок имеют как бы двойное обоснование: подлинное, через внутреннюю логику опыта, и ложное, с помощью понятийной логики богословской доктрины, напоминающее собой народную этимологию. Вторая логика представляет отдельный и не сводимый к опыту интерес, ибо обнаруживает средневековую культуру в ее предельном самораскрытии, в напряженных попытках выразить невыразимое - неважно, есть оно или его нет - в момент продуктивной самокритики, предельной мобилизации ее логических и языковых возможностей. Однако богословская доктрина не только обосновывает опыт, но в оборотном движении влияет на него и видоизменяет его, пример чему имеем в созерцании простых, пронизанных светом геометрических форм, воспитанных 2-й волной неоплатонизма («Книга о причинах», «Книга 24 философов»).

\section{II. Транскрипция опыта}

\section{1. Внутренняя атрибутивная аналогия}

Теоретические выкладки «рейнских мастеров», прежде всего И. Экхарта, предлагают понятийный слепок духовного делания, осуществлявшегося харизматиками обоих полов, в том числе бегинками и доминиканками. Основу этого делания составляла так называемая перформативная практика - imitatio Christi, подражание Иисусу Христу, организовавшее вокруг себя аскетические упражнения. Харизматик, тот же Г. Сузо, не просто умерщвлял свою плоть - постом, отказом, сокращением сна, ношением вериг (шипов, перевязей, гирь), переохлаждением и многочасовыми молитвами, - но умерщвлял плоть свою так, как умерщвляли Христа: «И вот, соорудил он себе из дерева крест, бывший длиной с вытянутую руку мужчины и имевший обычную ширину. В него он вбил XXX железных гвоздей, особенно памятуя обо всех ранах Господних и о пяти Его знаках любви. Сей крест он приладил на свою обнаженную спину меж плеч, к самой плоти, и восемь лет постоянно носил его денно и нощно во славу распятого Господа» [Сузо, 2014, 40]. «Он вытащил свою плетку с колючими шпильками и начал бить сам себя по телу, рукам и ногам, так что кровь потекла струйками вниз, словно при кровопускании. <..> Он стоял окровавленный и осматривал себя: вид его был плачевным, в некотором роде он походил на Христа, нашего Господа, когда Того подвергали ужасному бичеванию» [там же, 42].

И вот в латинских трудах И. Экхарта мы находим теоретическое обоснование перформативной практики. Им стало учение об аналогии. Основываясь на онтологии Фомы Аквинского, Экхарт пришел в своем «Трехчастном труде» к простой и, если вдуматься, парадоксальной мысли: подобие двух и больше явлений не предполагает в обязательном порядке их принадлежности к единому роду; принадлежность к разным родам никоим образом не предполагает их неподобия. Можно в одно и то же время различаться по существу, относясь к разным родам и уровням бытия, и отождествляться не по существу, получая принципы своего строения извне и осуществляя эти принципы на материале, иноприродном 
по отношению к исходному образцу. Совокупность таких принципов - существующих объективно, безразличных к тому или иному субстрату, готовых реализоваться на всяком субстрате и организовать его в соответствии с собой, - называется формой. Именно форма, а вовсе не родственные или причинно-следственные отношения, представляет собой сущность подобия и аналогии (если быть точнее, «внутренней атрибутивной аналогии»). При известном заострении и некоторой доводке такое логическое построение может адекватно и, с точки зрения Церкви, корректно выразить аскетико-мистический опыт как доминиканок, так и облагодатствованных мирянок, в том числе бегинок ${ }^{1}$.

Ещё раз - о том же, используя метафорику Экхарта. Прообраз и образ, человек и его статуя связаны единством формы. По существу они не тождественны, ибо человек живой, статуя же высечена из дерева или из камня, но не по существу они тождественны, у них одинаковый силуэт, рост, цвет и прочее. Так же соотнесены Христос и харизматик. Между ними имеется не сущностное тождество сущностно не тождественного. Именно такое тождество позволяет И. Экхарту говорить о «сынах [Божьих] аналогическим образом (analogice)» [Майстер Экхарт, 2001, 301-302].

Это - метафизика аналогии, однако имеется и ее практика. И такая-то практика есть не что иное, как имитационная аскеза, «игра» (spil, ludus) в Иисуса Христа: равняясь в аскетических упражнениях на Спасителя, харизматик не становится Спасителем, но становится таким, как Спаситель. Оставаясь по существу собой, он обретает не сущностное, а формальное сходство с Христом - в смысле устроения своего быта по подобию с жизнью Христовой, и, как итог, себя самого по подобию со Христом; он - христос в «игре», воссоздавая (как режиссер) и переживая (как актер) ровно то самое, что довелось пережить и Христу, хотя и не Христос вне «игры». Впрочем, эта «христоподобная» (cristfoermig) opганизация [Seuse, 1907], эта совокупность формальных принципов, понимается в пределах двойного обоснования через опыт и через доктрину не только как результат сознательной практики себя, но и как некоторая сообщенная харизматику метафизическая реальность: «сердце Отцово любовно и безо́бразно изрекло в его сердце Вечную Мудрость» [там же, 2014, 137], Христа. Харизматик становится Христом «по благодати» (genedeklich) [там же, 145]. Это есть результат его произвольных усилий, хотя им самим толкуется как дар, независимый от усилий, развиваемых им.

\section{2. Субсистенщия}

Учение рейнских мастеров об аналогии имеет своим средоточием теорию субсистенции. Наряду с немецкими теологами и мистиками последующих столетий - Николаем Кузанским, Якобом Бёме, Ангелом Силезским - они выстраивали свое богословское учение вокруг формулы «totus intus, totus foris» («(Бог) целиком внутри и целиком снаружи (тварного мира)»). В главе 3 автобиографии Сузо о божественной Премудрости написано: «Она всему соприсутствовала и была все-таки скрыта» [Сузо, 2014, 20]. В рамках простонародных ересей высокого и позднего Средневековья эта центральная для любой богословской системы формула не получила надлежащего осмысления, понимаясь то в дуали-

${ }^{1}$ Ср.: «В пределах схоластической метафизики учение об аналогии имело задачу определить отношение между сотворенным и несотворенным». Целью этого учения было «избежание альтернативы, состоявшей в том, чтобы, с одной стороны, принимать монистическое толкование бытия, лишенного различий и градаций, а с другой стороны, разделять дуалистический взгляд на бытие». Учение об аналогии «объясняло отношение сотворенного и несотворенного как подобие - несмотря на все их различие» [Hasebrink, 1992: 93]. См. по теме: [Косh 1964], из современных работ: [Schiffhauer 2005]. В рамках отечественной науки теория формальной (смысловой) эманации начала разрабатываться философами «Серебряного века», затем параллельно участниками Парижского богословского кружка и А.Ф. Лосевым на материале произведений Г. Паламы (учение об энергиях) и его адептов (Давид Дисипат и др.). 
стическом «totus foris» (катары), то в пантеистическом «totus intus» (бегарды, секта «Свободного духа») ключе. При этом Бог уподоблялся материальному объекту, который только и может находиться либо внутри, либо вне того или иного объема, и никак иначе.

Но Бог, как считают И. Экхарт и Г. Сузо, является интеллигибельным, умозримым объектом, иначе говоря, субсистенцией, то есть реальностью, никак не поддерживающей бытия акциденций (качества, отнесенности к пространству, времени) и по этой причине неописуемой с помощью предикатов существования. Бог не принадлежит предметному миру, и законы этого мира на него не распространяются. Бог может быть одновременно и вне, и внутри, подобно прообразу и образу, в котором представлен этот прообраз. Будучи сущностно нетождественными, Бог и сотворенный им мир могут быть несущностно тождественными - как человек и изображение этого человека на пергаменте либо доске. Они не совпадают друг с другом, иначе образ не был бы образом, но и не чужды друг другу, иначе прообраз не был бы прообразом, а отличны (differens) друг от друга.

Воспроизведем ход рассуждений И. Экхарта в его 2-й диспутации. Гипотетически допустив, что образ человека есть нечто сущее, Экхарт задается вопросом об отношении этого существующего образа к существующему же человеку. Здесь, как и в приложении к любым тварным вещам, допустимы две альтернативы: либо человек и его образ тождественны, либо чужды друг другу. Но первое невозможно, ведь тогда человек должен быть представлен в глазу наблюдателя собою самим и ему самому нужно присутствовать в этом глазу. Однако и второе едва ли возможно, ведь тогда образ, став принципом познания чего-то другого, не был бы «принципом познания человека». Чтобы выполнять свою функцию, образ должен быть не тождествен и не чужд человеку; а это невозможно для вещи, которая существует. Следовательно, образ не может быть сущим, и, в качестве не существующего, он должен быть столь же тождествен, сколь и чужд человеку; а быть своему объекту одновременно тождественным и чуждым означает быть с ним различным [Eckhart, 2000, vol. 5, 52].

Занятый доказательством несуществования знака (а если точнее, значения знака), Экхарт до поры не вводит термина «различие». Но он введет его позже, именно в пункте 367 «Толкования на Евангелие от Иоанна»: «Знак - то же самое (что и вещь. - M.Р.) по природе, различный (differens) по способу существования» [Eckhart, 2000, vol. 3, 312], и пояснит в латинской проповеди 50: «Нельзя было бы утверждать, что я вижу человека либо (какой-то) цвет, если бы образ (species) цвета или даже самый цвет, но в ином бытии (sub alio esse), или, скорей, то же бытие, но иным способом (sub alio modo), не присутствовало в глазу» [Eckhart, 2000, vol. 4: 430].

В латинской проповеди 49 / 2 мистик привлечет для развития своей мысли неоплатоновскую формулу: «свое иное» (se alterum, in se altero) [Eckhart, 2000, vol. 4, 425]. После кончины Мастера триаду «разделение (underschidunge) - различение (underscheidenheit) тождество (glihheit)», введет в своей «Книжице Истины» и в богословских главах 46-53 автобиографии «Vita» Г. Сузо [2014, 435] в ходе борьбы с современной ему, примыкающей вплотную к его мистическому направлению пантеистической ересью «Свободного духа»... Повторим: способность различаться с собой, находиться в себе и вне себя, быть представленным не только собой, но и в ином бытии, в форме «своего инобытия» есть коренное отличие несотворенных и сотворенных предметов, или, как бы сегодня сказали, интеллигибельных и феноменальных объектов.

1. Возникает вопрос: какое отношение теория субсистенции имеет к духовной практике монахинь 1-й половины XIV века? Что именно в их мистико-аскетическом опыте осмысляется и транскрибируется посредством этой теории? Ответ мы находим в посмертной апологии Элсбет фон Ойе, где присутствие Божие в мире уподобляется звучащему слову (red). Как слово, оставаясь в устах у того, кто его произносит, проникает в уши тому, кто внемлет ему, так Бог, пребывая в себе, одновременно обретается в сотворенном им мире [Apologie..., 2009, 460]. Такое высказывание допускает и прямое, не метафорическое толкование: цюрихская монахиня постоянно имела аудиции, слышала 
раздающиеся в ней голоса Бога и каждой из его ипостасей, а также небесных насельников, которые понимала не психологически, как свою психическую продукцию, а онтологически, как откровение свыше. Иначе говоря, субсистенция - это метафизика тех содержаний, которые харизматик получал в явлениях, видениях, в аудициях, а также во снах. Снимая оппозицию «внутри» и «снаружи», нерелевантную для «виртуальных» (in virtute) [Eckhart, 2000, vol. 5: 45-46] объектов, субсистенция с присущим ей и только ей «различением» могла объяснить, ка́к Бог может находится за пределами тварного мира и одновременно в сердце у каждого харизматика.

\section{3. Духовные совершенства}

Ярким примером субсистенции являются так называемые «духовные совершенства» (perfectiones spirituales). Духовные совершенства экхартовской метафизики, представляющие собой адресованные людям эманации Божьи, описывались французскими, а затем немецкими неотомистами по четырем параметрам: 1) совершенства существуют до своих тварных субъектов-носителей; 2) существуют и после них, и когда те исчезают, они остаются; 3) совершенства не получают бытие от субъектов, но, наоборот, сообщают им свое бытие; и, наконец, 4) сами субъекты (не в качестве сотворенных людей, но в качестве людей мудрых, несотворенных, праведных, вечных и пр.) существуют «постольку, поскольку» (inquantum, intantum; als, als): в ту и только в ту меру, в какую способны приобщаться духовным совершенствам: несотворенным, вечным и неделимым [Ebeling, 1941, 160-161]. В основных чертах и в общедоступном виде учение о духовных совершенствах излагается Экхартом в главе 1 «Книги божественного утешения» [Экхарт, 2010, 40-43].

Однако систематическую разработку оно получило в пунктах 14-22 экхартовского «Толкования на Евангелие от Иоанна» на примере пары праведника и Праведности. Доминиканский теолог выделяет четыре позиции: Божество, Праведность не рожденную, рожденную Праведность и праведника. Два средних члена, не рожденная и рожденная Праведность, - это (наряду с Благостыней, Истиной, Святостью, Мудростью) одно из духовных совершенств, взятое с двух разных сторон: применительно к Богу и применительно к человеку, и являющееся, если прибегнуть к терминологии экхартовской теории образа, Богом «в Своем ином» (in se altero) и «иным способом» (sub alio modo) божественного бытия. По поводу четвертого члена, праведника, нужно заметить, что Экхарт называет его «темным» праведником «самим по себе» (in se ipso) и противопоставляет его обитающему в нем же Праведнику «как таковому» (ut sic). Этот последний, Праведник «как таковой», есть не что иное, как рожденная / не рожденная Праведность, Бог. Три первых члена всей четверицы (Бог, Праведность не рожденная, рожденная Праведность, или иначе, Праведник «как таковой») - однородные, соименные сущности (univoca), связанные озадачивающим отношением «порождения» (generatio). Однако о пантеизме тут говорить не приходится, ведь последний член названной триады, рожденная Праведность (Праведник «как таковой»), связана с темным праведником «самим по себе» исключительно аналогическим образом (analogia); праведник «как таковой» и праведник «сам по себе» - это две разнородные сущности, связанные друг с другом несущностным тождеством [Eckhart, 2000, vol. 3: 13-19]. Будучи по существу отличным от сотворенного праведника «самого по себе», нетварный Праведник «как таковой» оповещает его о себе (informare), тем самым преобразуя его (reformare) и уподобляя себе (conformare). Говоря иначе, он видоизменяет его в соответствии со своими принципами организации, но оставляет его полностью инородным себе.

Рассмотренное учение представляет собой транскрипцию того разговора, который ведут Христос (Праведник «как таковой») и душа (Праведник «сам по себе»), со-восседая в сердце у харизматика, у бегинки или доминиканки. Весь смысл христианской жизни, согласно И. Экхарту, заключается в том, чтобы пробиться от себя «самого по себе», темного, твар- 
ного и преходящего, к иноприродному себе «как таковому», светлому, нетварному, вечному, к своей «synteresis», искорке, рожденной Праведности (iustitia genita), к Божеству.

«Что было вверху, то стало внутри. Ты должен быть собран в единое, от себя самого в себя самого, дабы Он был в тебе, - а не так, чтобы нам брать от того, что над нами. Нам надобно это черпать в себе и брать от себя в нас самих» [Экхарт, 2010, 175].

\section{4. Мистическое единение}

Разработанное И. Экхартом в «Трехчастном труде» учение о праведнике и Праведности, в основе которого лежит теория различения, не замедлило сказаться на мистагогии его учеников. Некогда высказанное нами предположение, что за разрозненными и, повидимому, взаимоисключающими описаниями мистического единения (сотрудничество воль, диалог, инспирация, поглощение) в литературе монахинь стоит общий, один и тот же опыт, изображенный разве что с разных сторон и в разных моментах своего протекания, - это предположение в полной мере оправдывается на материале произведений Г. Сузо и И. Таулера. Схема такова: деятельное сотрудничество со стороны человека преследует упразднение его «самости» ${ }^{1}$ (индивидуальных свойств, стимулов к действию), что приводит к его наделению новыми качествами и мотивациями со стороны Бога, каковые, став его новым «хабитусом» (habitus), затем обнаруживаются в его поведении.

Такая динамика была запечатлена младшими рейнскими мастерами, наиболее же выразительно И. Таулером: «Если тебя привлекает Христос, предоставь Ему себя без форм и без образов и позволь Ему действовать, будь же Его инструментом» [Die Predigten..., 1968, 71]. «Если в тебе должен воистину действовать Бог, то ты должен пребывать в сплошной опустошенности от всего. Все силы твои должны отложиться от всей своей деятельности и своих обыкновений, оставаться в полном отречении от себя самое, должны обессилеть и находиться в своем чистом, обнаженном ничто. Коль скоро Богу надлежит воистину говорить, все силы обязаны замолчать; тут должно быть не действие, но должно быть бездействие» [там же, 314].

Взятые в действительном залоге формы глаголов «предоставь» (lo), «будь» (bis) и «должен» (můstu) указывают на активность действия харизматика, однако его «действие» (tůn) является на самом деле «бездействием» (entůn). И такое-то «действие-бездействие» является «опустошенностью» (lidekeit). Охваченный неизреченным Ничто (niht), которое, ввиду очевидности своих проявлений, несомненно, есть Нечто (iht) [Сузо, 2014, 145], «дух» человека уничтожается и исчезает. Впрочем, «уничтожение духа, его исчезновение в препростом Божестве <...> нельзя понимать в смысле такого преображения его сотворенной природы, что то, чем является он, является Богом, и <...> что дух становится Богом, а его собственная сущность обращается в ничто» [там же, 128].

Как же тогда понимать это самое «уничтожение» (vernihtkeit)? - А так, что «в <...> охваченности дух приходит как бы в забвение и к утрате себя самого [там же, 142$]^{2}$. «Смерть [духа] заключается в том, что в своем погружении (в Бога) он не различает собственной сущности. Но по возвращении из созерцания он различает себя с троицей Лиц, и каждой вещи различающим образом предоставляет быть тем, что она есть» [там же, 146].

Это второе «уничтожение» себя в смысле субъективного ощущения в экстазе (первое заключалось в приуготовительном отказе от «самости») восходит через «Книжицу Истины» раннего Г. Сузо [там же, 261] к экхартовскому трактату «О человеке высокого рода», где речь идет о двух фазах мистического единения: 1) «удалении» (осознании себя и своей активности) и 2) «возвращении» (утрате этого осознания): «Первое, в чем блаженство сокрыто, это то, что душа в чистоте взирает на Бога. Здесь берет она всю свою суть и

\footnotetext{
${ }^{1}$ «Selbsheit», «sinsheit» [Seuse, 1907, 187; 359].

2 «In der ingenomenheit kunt der geist neiswi in sin selbes vergessenheit und verlornheit» [Seuse, $1907,182]$.
} 
свою жизнь и творит все, что она есть, из основания Бога и не ведает о знании, о любви и ни о чем вообще. Она обретает покой только и единственно в сущности Божьей; она не сознает, что́ здесь сущность и Бог. Но если бы она знала и понимала, что она Бога видит, созерцает и любит, то это, в соответствии с естественным порядком вещей, было бы удалением, а (затем) возвращением в исходное» [Экхарт, 2010: 71].

Пережив мистическое единение, харизматик обменивает свои свойства и действия на свойства и действия Бога и начинает определяться «духовными совершенствами»: «Дух <..> становится обездушенным, в смысле утраты свойств, которыми некогда обладал» $[\text { Сузо, 2014, 142] }]^{1}$ « «ух же утрачивает свое своеволие, прекращается как самостоятельный деятель» $[\text { там же, 144] }]^{2}$. «Он обретает некие свойства Божества, хотя не становится Богом по естеству» ${ }^{3}$. Дух, сверх своих природных возможностей, возводится, посредством силы лучащейся светом божественной сущности, в наготу оного Ничто» [там же, 146] $]^{4}$.

В немецких трактатах и проповедях Экхарта мистическое единение изображается с привлечением иллюминативных мотивов. Не принадлежа харизматику, искорка - «synteresis» (Праведник «как таковой», Христос в душе) освещает душу, в которой пребывает, будучи ей инородной, а через душу и самое тело: «От переизбытка свет, находящийся в основании души, изливается в тело, и тело полностью просветляется» [[Deutsche Mystiker..., 2: 12; см. также: Sanctæ Gertrudis..., 101]. Метафора солнечного света сплошь и рядом используется рейнскими мастерами для изображения аналогического воздействия Бога на иноприродный, сотворенный им мир; мир этот, в случае мистического единения, включает в себя не только душу харизматика, но также весь его душевный и телесный состав [Реутин, 2011, с.114].

\section{III. Заключение}

В научной литературе много спорят о так называемой второй волне неоплатонизма, зародившейся на излете Высокого средневековья и принесшей полноценные плоды в схоластике 1-й половины XIV в. Ее основными вехами стали переводы «Книги о причинах» (до 1187 г.) и «Путеводителя растерянных» Моше бен Маймона (1-я половина XIII в.), а также создание «Книги XXIV философов» (2-я половина XII в.). К этой волне относится деятельность друга Фомы Аквинского, переводчика Уильяма де Мёрбеке («Первоосновы теологии» до 1268 г., «Толкование на “Парменид”» Прокла, «Парменид» Платона (гипотеза I, до 1286 г.) и оживление интереса к платоновскому «Тимею» в изложении Халцидия (1-я половина IV в.). На переводах У. де Мёрбеке во многом строилась программа studium generale, Высшей школы доминиканцев в Кёльне, возглавляемой И. Экхартом, а затем Бертольдом Моосбургским, комментатором «Первооснов теологии» Прокла. Насколько мы можем судить, школа эта отчасти противопоставляла себя парижскому богословию. Напомним, что главным вопросом «Второй волны неоплатонизма» стал вопрос эманации (природной, натуральной или смысловой, формальной) и связанная с ней диалектика символа.

По умолчанию делается допущение, что ко «Второй волне» привели имманентные процессы развития философии. Однако, будучи, как в нашем случае, транскрипцией опыта, философия, как представляется, могла получать стимулы к своему развитию извне, из того са́мого опыта, транскрипцией которого она претендовала быть. Опыт этот сложился в эпоху «открытия индивида» во 2-й половине XII в. - в эпоху миннезанга, куртуазного романа, перехода от старой визионерской к новой мистической традиции. Последняя строилась по законам имитационной аскезы («imitatio Christi»), предполагая в качестве главного события в жизни харизматика интроекцию, рождение Бога в душе. В порядке допущения

\footnotetext{
${ }^{1}$ «Der geist $<\ldots>$ wirt entgeistet nah besizlicher eigenschaft dez sinsheit» [[Seuse, 1907, 182-183].

${ }^{2}$ «Der geist verlúret sin selbsheit; er vergat na sin selbs wurklichkeit» [Seuse, 1907, 185].

3 «Er gewinnet wol etliche eigenschaft der gotheit, mer er wirt doch naturlich got nit» [Seuse, 1907, 188].

${ }^{4}$ «So wirt der geist mit dez goetlichen liehtrichen wesens kraft geruket úber sine natúrlich vermugentheit in diss nihtes blossheit» [Seuse, 1907, 188].
} 
мы можем предположить, что 2-я волна неоплатонизма была во многом вызвана перформативными практиками, процветавшими как в монастырской, так и в городской, прихрамовой среде. Ведь помимо эманации, схоластика не имела понятийного инструментария, чтобы внятно объяснить мотив интроекции (проникновения Бога в душу в виде луча, потока огненной благодати и под.). Мотив же этот, становясь всё более популярным, настойчиво требовал себе объяснения. Если бы не возникло церковно-ортодоксального объяснения, то появилось бы еретическое. Применительно к нашему конкретному случаю, мы можем предположить, что опыт бегинок и монахинь-харизматиков задавал общий вектор в развитии философии «рейнских Мастеров» (как теперь говорят, «повестку дня»); на этот внешний вызов они отвечали переакцентуализацией, перестроением имеющегося у них философского знания ${ }^{1}$ (включая трактат «О разделении природы» Эриугены 862867 г.) к мобилизации заложенных в нем возможностей. Так выглядел очередной - внешне простимулированный, но обеспеченный внутренними ресурсами - виток в органическом процессе развития философского знания.

\section{Список литературы}

1. Майстер Экхарт. 2001. Об отрешенности. Сост., пер. со средневерхненем. и лат. яз., предисл. и примеч. М.Ю. Реутина. М., СПб.: Университетская книга. 432 с.

2. Майстер Экхарт. 2010. Трактаты и проповеди. Пер. М.Ю. Реутин; Изд. подгот. М.Ю. Реутин. М., Наука. 443 с.

3. Реутин М.Ю. 2011. «Христианский неоплатонизм» XIV века. Опыт сравнительного изучения богословских доктрин Иоанна Экхарта и Григория Паламы. М., Изд-во РГГУ. 246 с.

4. Сузо Г. 2014. Exemplar. М., Научно-издательский центр "ВРС"-"Ладомир". 597 с.

5. Элизабет Штагель. 2019. Житие сестёр обители Тёсс. М., Ладомир: Наука. 600 с.

6. Apologie zu Leben und Offenbarungen der Elsbeth von Oye. Hrsg. von Schneider-Lastin W. Kulturtopographie des deutschsprachigen Südwestens. Brl.; N. Y., 2009: pp. 458-462.

7. Deutsche Mystiker des vierzehnten Jahrhunderts: In 2 Bd. Hrsg. von Fr. Pfeiffer. Bd. 2. Lpz., 1845-1857.

8. Die Predigten Taulers. Aus der Engelberger und der Freiburger Handschrift sowie aus Schmidts Abschriften der ehemaligen Strassburger Handschriften. Hrsg. von F. Vetter. Frankfurt (am M.), 1968.

9. Dinzelbacher P. 2012. Deutsche und niederländische Mystik des Mittelalters. Ein Studienbuch. Brl.; Boston. 432.

10. Ebeling H. 1941. Meister Eckharts Mystik. Studien zu den Geisteskämpfen um die Wende des 13. Jahrhunderts. Stuttgart, 1941: pp. 51-73.

11. Grundmann H. 1935. Religiöse Bewegungen im Mittelalter. Untersuchungen über die geschichtlichen Zusammenhänge zwischen der Ketzerei, den Bettelorden und der religiösen Frauenbewegung im 12. und 13. und über die geschichtlichen Grundlagen der deutschen Mystik. Brl. 580 p.

12. Hasebrink B. 1992. Formen inzitativer Rede bei Meister Eckhart. Untersuchungen zur literarischen Konzeption der deutschen Predigt. Tübingen. 306 p.

13. Koch J. 1964. Zur Analogielehre Meisters Eckhart. Altdeutsche und Altniederländische Mystik. PP. 275-308.

14. Meister Eckhart. 2000. Die lateinischen Werke: In 5 Bd. Stuttgart.

${ }^{1}$ В качестве примера переакцентуализации можно привести, в частности, использование Экхартом фомистского термина «genero» (порождать). Аквинатом он использовался применительно к однородным, соименным сущностям (в том числе к ипостасям Троицы, человеку), Экхартом применительно к формальному порождению разнородных сущностей: прообразом раскладки образов, связанных, при их сущностном нетождестве, несущественным тождеством, т.е. подобием. Другой пример: замена ангельской иерархии псевдо-Дионисия на непосредственный контакт Бога и человека. Ср.: «Господи, небеса для меня слишком ничтожны <..> утешение ангелов почитаю я за ничто <...>. Господи, если Ты хотя бы немного любишь и ценишь меня, тогда приди Сам и не присылай ко мне никакого посланника» [Элизабет Штагель. 2019, 163, 442]. 
15. Sanctæ Gertrudis Magnæ virginis ordinis sancti Benedicti Legatus divinæ pietatis. In: Revelationes Gertrudianæ ac Mechtildianae: in 2 Vol. / Opus ad codicum fidem nunc primum integre editum solesmensium O.S.B. monachorum cura et opera. Pictavii; Parisiis, 1875-1877. Vol. 1. P. 1-613.

16. Schiffhauer A. 2005. «Nos filii dei sumus analogice». Die Analogielehre Meister Eckharts in der Verteidigungsschrift. In: Meister Eckhart in Erfurt. Brl.; N.Y.: 356-392.

17. Seuse H. 1907. Deutsche Schriften. Hrsg. von K. Bihlmeyer. Stuttgart. 230 p.

\section{References}

1. Mayster Ekkhart 2001. About detachment. Compiled, translated, preface and notes by M. Yu. Reutin. M., St. Petersburg, University Book Publishing House. 432 p.

2. Meister Eckhart. 2010. Treatises and sermons. translated by M.Y. Reutin; edition of podgot. ovil M.Yu. Reutin. M., Nauka Publ. 443 p.

3. Suzo G. 2014. Exemplar. [Exemplar]. M., Publ. Nauchno-izdatel'skiy tsentr "VRS""Ladomir". 597 p.

4. Reutin M.Yu. 2011. «Khristianskiy neoplatonizm»XIV veka. Opyt sravnitel'nogo izucheniya bogoslovskikh doktrin Ioanna Ekkharta i Grigoriya Palamy ["Christian Neoplatonism" of the XIV century. The experience of a comparative study of the theological doctrines of John Eckhart and Gregory Palamas]. M., Publ. RGGU, 246 p.

5. Elizabet Shtagel'. 2019. Zhitiye sestor obiteli Toss. [The life of the sisters of the Tess monastery]. M., Publ. La-domir, Nauka, 600 p.

6. Apologie zu Leben und Offenbarungen der Elsbeth von Oye. Hrsg. von Schneider-Lastin W. Kulturtopographie des deutschsprachigen Südwestens. Brl.; N. Y., 2009: pp. 458-462.

7. Deutsche Mystiker des vierzehnten Jahrhunderts: In 2 Bd. Hrsg. von Fr. Pfeiffer. Bd. 2. Lpz., 1845-1857.

8. Die Predigten Taulers. Aus der Engelberger und der Freiburger Handschrift sowie aus Schmidts Abschriften der ehemaligen Strassburger Handschriften. Hrsg. von F. Vetter. Frankfurt (am M.), 1968.

9. Dinzelbacher P. 2012. Deutsche und niederländische Mystik des Mittelalters. Ein Studienbuch. Brl.; Boston. 432.

10. Ebeling H. 1941. Meister Eckharts Mystik. Studien zu den Geisteskämpfen um die Wende des 13. Jahrhunderts. Stuttgart, 1941: pp. 51-73.

11. Grundmann H. 1935. Religiöse Bewegungen im Mittelalter. Untersuchungen über die geschichtlichen Zusammenhänge zwischen der Ketzerei, den Bettelorden und der religiösen Frauenbewegung im 12. und 13. und über die geschichtlichen Grundlagen der deutschen Mystik. Brl. 580 p.

12. Hasebrink B. 1992. Formen inzitativer Rede bei Meister Eckhart. Untersuchungen zur literarischen Konzeption der deutschen Predigt. Tübingen. 306 p.

13. Koch J. 1964. Zur Analogielehre Meisters Eckhart. Altdeutsche und Altniederländische Mystik. PP. 275-308.

14. Meister Eckhart. 2000. Die lateinischen Werke: In 5 Bd. Stuttgart.

15. Sanctæ Gertrudis Magnæ virginis ordinis sancti Benedicti Legatus divinæ pietatis. In: Revelationes Gertrudianæ ac Mechtildianae: in 2 Vol. / Opus ad codicum fidem nunc primum integre editum solesmensium O.S.B. monachorum cura et opera. Pictavii; Parisiis, 1875-1877. Vol. 1. P. 1-613.

16. Schiffhauer A. 2005. «Nos filii dei sumus analogice». Die Analogielehre Meister Eckharts in der Verteidigungsschrift. In: Meister Eckhart in Erfurt. Brl.; N.Y.: 356-392.

17. Seuse H. 1907. Deutsche Schriften. Hrsg. von K. Bihlmeyer. Stuttgart. 230 p.

\section{ИНФОРМАЦИЯ ОБ АВТОРЕ}

Реутин Михаил Юрьевич, доктор философских наук, кандидат филологических наук, ведущий научный сотрудник Института общественных наук Российской академии народного хозяйства и государственной службы при Президенте РФ

\section{INFORMATION ABOUT THE AUTHOR}

Mikhail Ju. Reutin, doctor of Philology, candidate of Philology, leading researcher Of the Institute of social Sciences of the Russian Academy of national economy and public administration under the President of the Russian Federation 